\title{
Path Analysis on the Effects of Psychosocial Development, Nutritional Status, and Family Acceptance on Learning Achievement in Autistic Children, in Jember, East Java
}

\author{
Tutut Okta Diana'), Didik Tamtomo'), Bhisma Murti 1) \\ 1)Masters Program in Public Health, Universitas Sebelas Maret \\ 2)Faculty of Medicine, Universitas Sebelas Maret
}

\begin{abstract}
Background: The prevalence of autism has been increasing worldwide annually. Autistic children are at higher risk of physical, mental, and intellectual disorders. However, autistic children may have above average academic achievement. With support from family, teacher, and society, autistic children can gain maximum academic achievement. This study aimed to determine the effects of psychosocial development, nutritional status, and family acceptance, on learning achievement in autistic children, in Jember, East Java.

Subjects and Method: This was an analytic observational study with cross-sectional design. The study was conducted at Special Elementary School in Jember, East Java. A total sample of 50 autistic students were collected for this study by exhaustive sampling. The dependent variable was learning achievement. The independent variables were nutritional status, psychosocial development, and family acceptance. The data were collected by questionnaire and analyzed by path analysis.
\end{abstract}

Results: Learning achievement was directly affected by psychosocial development $(b=0.36 ; \mathrm{SE}=$ $0.13 ; \mathrm{p}=0.005)$ and nutritional status $(\mathrm{b}=1.42 ; \mathrm{SE}=0.65 ; \mathrm{p}=0.029)$. Nutritional status was positively affected by strong family acceptance $(b=0.07 ; \mathrm{SE}=0.01 ; \mathrm{p}<0.001)$.

Conclusion: Learning achievement of autistic children is affected by psychosocial development and nutritional status.

Keywords: learning achievement, psychosocial development, nutritional status, family acceptance, path analysis

Correspondence:

Tutut Okta Diana. Masters Program in Public Health, Universitas Sebelas Maret, Jl. Ir. Sutami 36 A, Surakarta 57126, Indonesia. Email : tutut_od@yahoo.co.id. Mobile: +6281335466569.

\section{BACKGROUND}

Autism is a central nervous system
development syndrome that is found in a number of children in their childhood until the later stage (Purwati, 2007). General parental or familial reactions to the presence of children with autism can vary (YPAC, 2014). Rejection toward children with autism is not only done by other individuals, but also are usually done by their own family. Various treatments were experienced by them, starting from smooth evasion, direct rejection, to attitudes and treatments that tend to be less humane
(Werner, 1987). The treatment can affect the growth and development of the children. Parents who are able to accept the existence of children with autism will be able to play a role in child care better and will pay more attention to the needs of children such as the needs of children's vitamins, drugs, therapy and education and diet and nutrition of children (Pancawati, 2013). Praweswari (1999) argued that the role of parents is the contribution of parents in providing good preparation for their children for the success of education that is implemented. Parents' role indicator 
is the attention to children's school activities and emphasizes the importance of achieving the learning achievement".

Learning achievement according to Gagne (in Dimyati, 1999) is the capability that is acquired from the learning activities in the form of skills, knowledge, attitudes and set of values. Learning achievement is influenced by internal factors such as psychology, physical, physiological, senses and external factors including environmental, social, instrumental (Slameto, 2010, Wasis, 2001, Setiawati et al., 2002).

Psychological and social factors can be done with psychosocial stimulation. Psychosocial stimulation is the education stimulation done in order to develop cognitive, physical or motor skills, as well as social-emotional of the children (MoNE 2003).

According to Erikson (1997) in Hastuti (2006), the development of the child in addition to the views of physical development is also seen from the intellectual, social, emotional, and moral development that Erikson expressed in four dimensions of psychosocial development. According to Boeree (2003), the factors that influence the learning achievement include genetic factors, nutritional factors and environmental factors. Genetic factors are closely related to heredity and disability conditions, while nutritional factors are related to the intake of food consumed, where the intake of food consumed depends on the pattern of parenting in the family. Gluten-free and casein-dependent diets in autistic children have been linked to health risks, one of concerns is the increase of nutritional risks. Based on a study of Martiani et al. (2012), the prevalence of autistic children with low nutrition status in SLBN Semarang is quite high that is $47.4 \%$ malnutrition status, $31.6 \%$ normal nutritional status and $21.1 \%$ more nutritional status. Meanwhile, according to Al-Farsi et al., (2011) the incidence of malnutrition in children of pre-school age autism in Oman is 9.2 per 100 children. Of the 128 respondents who followed the study, none were overweight or obese. Good nutrition is a balanced nutrition, meaning the intake of nutrients must be in accordance with the needs of the body (Supariasa, 2002).

Data from WHO (2014), World Bank (2014) and ILO (2014) show that the current number of people with autism in the world is estimated at $15 \%$ of the world's population or 1 billion people, and at least 785,000,00o (seven hundred eight five million) people with autism enter schoolage. Based on the Ministry of Social of Indonesia, in 2010, out of 14 provinces in Indonesia became the target of the survey, there were 1,167,111 people with autism (Irwanto et al., 2010). Meanwhile, the data of Susenas (2012) shows the population of Indonesia that bears disability equal to $2.45 \%$, and has increased when compared with Susenas 2003 and 2009. With the increase of number of autistic patients, so it requires roles of all parties so autistic children can grow and develop, both physically and psychosocially and they are also expected to achieve the maximum learning achievement. It has been proven that many of autistic children have intellectual ability above the average normal children.

The formulation of the problem in this study is "is there an influence of psychosocial development on learning achievement in children with autism?", "is there any influence of nutritional status to learning achievement in autistic child?", "is there any influence of family acceptance on learning achievement through nutritional status in children with autism?" The purpose of this study is to determine the influence of psychosocial development, 
nutritional status and family acceptance of learning achievement of autistic children in Jember.

\section{SUBJECTS AND METHOD}

\section{Study Design}

This was an analytic observational study with a cross sectional design. The data were collected at an extraordinary school in the Jember Regency area of 5 extraordinary schools in December 2015 - January 2016.

\section{Population and Sample}

Study population was all parents of autistic children and autistic children in the extraordinary elementary school of Jember region. Sampling method used in this study was exhaustive sampling technique. There were 50 children with autism and parents selected as samples.

\section{Study Variables}

There were four variables in this study consisting of independent and dependent variables. The independent variables were psychosocial development, family acceptance and nutritional status of autistic children. The dependent variable in this study was the learning achievement of autistic children.

\section{Operational Definition of Variables}

Psychosocial development was defined as a process of progressive change that shows how a child behaves in interaction with the environment or process of change in ability at a period of time as a function of maturity and interaction with the environment. The data were collected by questionnaire. The measurement scale was continuous.

The nutritional status was defined as the state of the body as a result of food consumption and the use of nutrients. The measuring instrument was a Z-score table (BB/age). The measurement scale was continuous.

Family acceptance was defined as a psychological effect and family behavior on the children, such as affection, attachment, caring, support and care in which the family can feel and express affection to their children. The measurement scale was continuous.

The learning achievement was defined as the mastery of knowledge or skills developed by the subjects, usually indicated by the value of the test or the value provided by the teacher. The measuring instrument was a learning result card (raport) with a continuous data scale.

\section{Data Collection Instrument}

The instruments for data collection were questionnaire and Z-score table. Questionnaires used for psychosocial development based on Vineland Social Maturity Scale (Doll, 1965), for questionnaire of acceptance of family, it had been tested for validity and reliability test.

\section{Data Analysis}

The analysis process was done using univariate analysis in order to see the characteristics of data and description of research variables. Bivariate analysis was done to analyze the influence of dependent variable on independent variables using chi-square test and path analysis was done to analyze the relationship pattern between variables and to know the direct and indirect influence of independent variable on the dependent variable.

\section{Research Ethics}

The research ethical clearance was obtained from the Research Ethics Committee at Dr. Moewardi Hospital, Surakarta, Central Java, Indonesia. Research ethics included issues such as informed consent, anonymity, confidentiality, and ethical clearance.

\begin{tabular}{l} 
RESULTS \\
\hline 1. Univariate analysis \\
Table 1 shows that out of the 50 parents of \\
children with autism, the majority of
\end{tabular}


parents' education (father) is higher education (58\%), while the majority of mothers' education was senior high school (42\%). For the occupation, children's

\section{Table 1. The Characteristics of Research Subjects}

\begin{tabular}{lcc}
\multicolumn{1}{c}{ Characteristics } & Frequency & \% \\
\hline Paternal Education & 29 & 58.0 \\
University & 14 & 28.0 \\
SHS (Senior High School) & 7 & 14.0 \\
JHS (Junior High School) & - & - \\
PS (Primary School) & & \\
Maternal Education & 19 & 38.0 \\
University & 21 & 42.0 \\
SHS (Senior High School) & 7 & 14.0 \\
JHS (Junior High School) & 3 & 6.0 \\
PS (Primary School) & & \\
Paternal Occupation & 23 & 46.0 \\
Civil Servant & 11 & 22.0 \\
Freelancer & 14 & 28.0 \\
Entrepreneur & 2 & 4.0 \\
Labor & - & - \\
Not Working & & \\
Maternal Occupation & 17 & 34.0 \\
Civil Servant & 5 & 8.0 \\
Freelancer & 4 & 6.0 \\
Entrepreneur & 3 & 42.0 \\
Labor & 21 & \\
Not Working & & \\
\hline
\end{tabular}

Table 2 shows that each variable has relatively small data variations. The mean describes the average value, while the Table 2. The Description of research variable

\begin{tabular}{|c|c|c|c|c|c|}
\hline Variable & $\mathbf{N}$ & Mean & SD & Min. & Max. \\
\hline $\begin{array}{ll}\text { Development } & \text { of } \\
\text { psychosocial } & \end{array}$ & 50 & 21.18 & 4.95 & 10 & 32 \\
\hline Nutritional Status & 50 & -0.26 & 0.98 & -2.50 & 2 \\
\hline Family Acceptance & 50 & 71.30 & 10.49 & 43 & 96 \\
\hline Learning Achievement & 50 & 71.47 & 4.99 & 56 & 83 \\
\hline
\end{tabular}

\section{Bivariate analysis}

Table 3 shows that the higher the nutritional status of children with autism is, the higher their learning achievement is. The higher the psychosocial development is, the higher the learning achievement is. The higher the family acceptance is, the higher the learning achievement is. parents (father), the majority of them were civil servants (46\%) while the majority of the mothers were not working (42\%).

standard deviation (SD) describes how far the data varies. A small SD is an indication that the data are representative. 
For Index $)=0.997(>0.90)$; CFI (Comparative Fit Index $)=1.00(>0.90)$; RMSEA (Root Mean Square Error of Approximation $)=<0.01(<0.08)$ which means that the

Table 3. Pearson correlation between psychosocial development, nutritional status and family acceptance with learning achievement of autistic children.

\begin{tabular}{lcc}
\hline \multicolumn{1}{c}{ Variable } & $\mathbf{r}$ & $\mathbf{p}$ \\
\hline Psychosocial Development & 0.38 & 0.006 \\
Nutritional Status & 0.31 & 0.027 \\
Family Acceptance & 0.21 & 0.135 \\
\hline
\end{tabular}

\section{Path analysis}

Table 4 showed that there was a positive effect of psychosocial development on learning achievement in autistic children. Autistic children with good psychosocial development were more likely to have good learning achievement than those with poor psychosocial development $(b=0.36 ; \mathrm{SE}=$ $0.13 ; \mathrm{p}=0.005$ ).

Table 4 showed that there was a positive effect of nutritional status on autistic children's learning achievement. empirical model meets the criteria specified and is stated as suitable with the empirical data.
Autistic children who have good nutritional status were more likely to have good learning achievement than those who have poor nutritional status $(b=1.42 ; \mathrm{SE}=0.65$; $\mathrm{p}=0.029$ ).

Table 4 showed that there was a positive effect of family acceptance on autistic children's nutritional status. Autistic children with strong family acceptance were more likely to have good nutritional status than those who have poor family acceptance $\quad(b=0.07 ; \mathrm{SE}=0.01 ; \mathrm{p}<0.001)$.

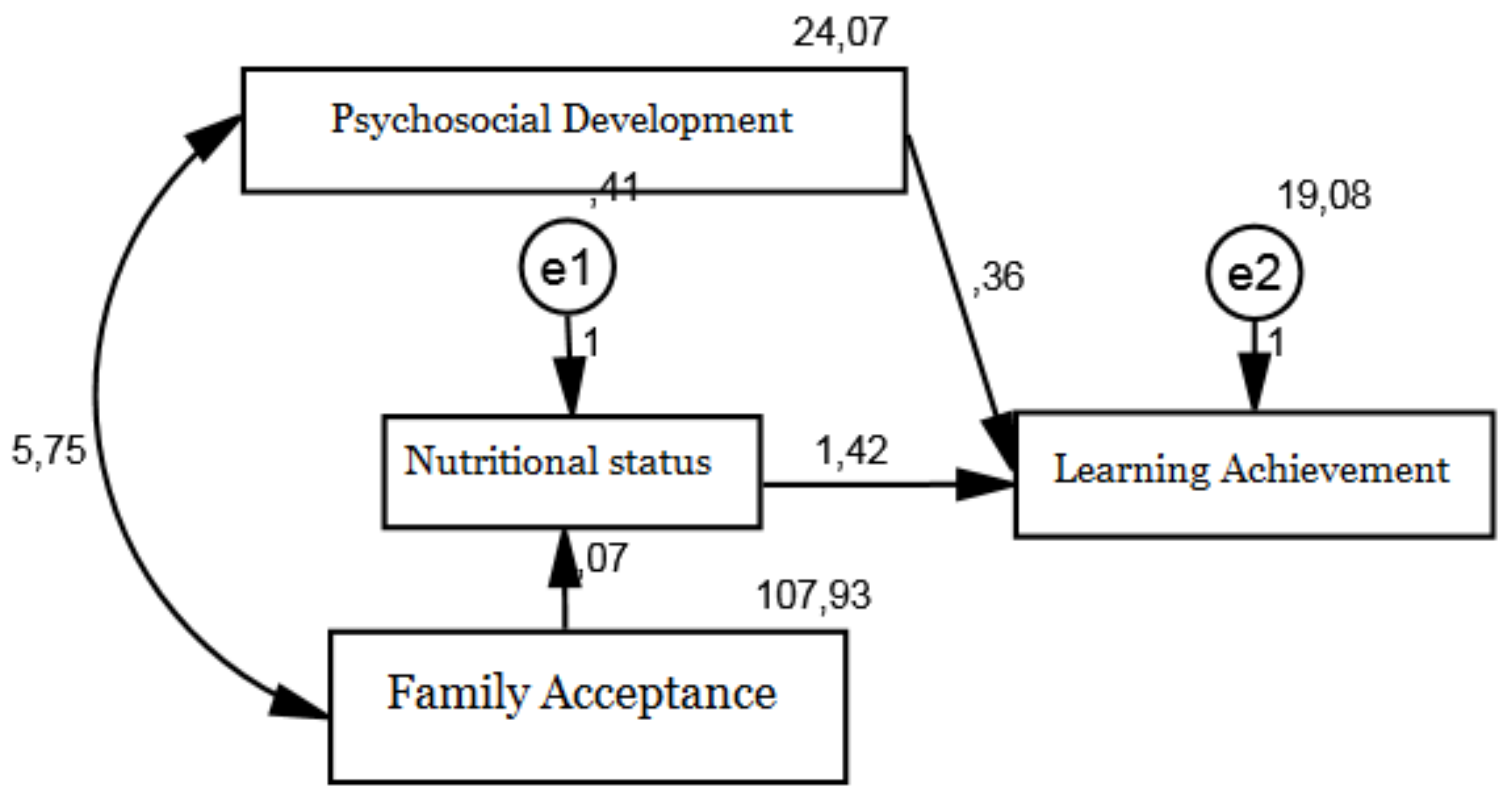

Figure 1. Structural model with unstandardized estimate 
Journal of Maternal and Child Health (2018), 3(1): 59-67

https://doi.org/10.26911/thejmch.201803.01.06

Table 4. The results of path analysis on the effect of psychosocial development, nutritional status and family acceptance of learning achievement among autistic children

\begin{tabular}{|c|c|c|c|c|c|c|}
\hline Dependent Variable & & Independent Variable & $\mathbf{b}^{*}$ & SE & $\mathbf{p}$ & $\boldsymbol{\beta}^{* *}$ \\
\hline \multicolumn{7}{|l|}{ Direct Effect } \\
\hline Learning Achievement & $\leftarrow$ & Psychological Development & 0.36 & 0.13 & 0.005 & 0.35 \\
\hline $\begin{array}{l}\text { Learning Achievement } \\
\text { Indirect Effect }\end{array}$ & $\leftarrow$ & Nutritional Status & 1.42 & 0.65 & 0.029 & 0.28 \\
\hline Nutritional Status & & Family Acceptance & 0.07 & 0.01 & $<0.001$ & 0.75 \\
\hline $\begin{array}{l}\text { Observation Score }=50 \\
\text { Fit Model: } \\
\text { CMIN= } 0.18\end{array}$ & $\begin{array}{l}\text { NFI } \\
\text { CFI } \\
\text { RM } \\
\mathrm{p}=\end{array}$ & $\begin{array}{l}=0.98 \\
1.00 \\
\mathrm{EA}<0.01 \\
.913\end{array}$ & & & & \\
\hline $\begin{array}{l}b=\text { unstandardized path } c \\
\beta=\text { standardized path coe }\end{array}$ & $\begin{array}{l}\text { effici } \\
\text { icien }\end{array}$ & & & & & \\
\hline
\end{tabular}

\section{DISCUSSIONS}

\section{The effect of psychosocial develop- ment on the learning achievement of autistic children}

A good psychosocial development was characterized by good social interaction with the surroundings. Therefore, autistic children have slower psychosocial development than normal children. The difficulty of autistic children to establish social interaction does not mean that they did not want or did not have an interest in social interaction, but they need help to understand the social situation and to respond properly. With support from the environment (parents, teachers, and people around them) children with autism can learn and get learning achievement at school (Oktaviani, 2008).

The result of path analysis in this study showed that there was a direct positive effect between psychosocial development and learning achievement of autistic children. Good psychosocial development allowed autistic children to be more able to develop their ability in various aspects such as; doing simple activity (put the garbage), more independent to fulfill their needs (shower, change clothes), playing with friends (the autistic children tend to enjoy in their own world) and understand what other people said (for example when the teacher said "Please open your book on page 1 " and they were able to do it). When the autistic children were able to understand what other people said, then they can perform the task given by the teacher. Therefore, this may affect their learning achievement in school.

The result of this study was in line with a study done by Fauzi et al. (2014) which stated that there was a relationship between emotional intelligence with learning achievement in students of SMP Negeri 22 Bandar Lampung. According to the theory postulated by Erik Erikson (psychosocial theory), there are four dimensions of psychosocial development, namely intellectual, emotional, social, and moral development. When a child was able to cultivate his/her emotions well, it can be said that the child has a good emotional intelligence.

\section{The effect of nutritional status on learning achievement}

Autistic children have a very sensitive tasting device, they just like certain foods. They did not want to taste other foods. Most of them did not like vegetables and fruits. Some even live from milk and instant noodles with chocolate as the 
snack. Children with autism usually have poor nutritional status and more nutrition. They often have poor digestion (about 25\% have chronic diarrhea and 25\% have constipation) and intestinal inflammation conditions that limit the nutrient absorption (Budhiman, 2010).

The result of path analysis in this study showed that there was a direct and significantly positive effect of nutritional status on learning achievement of autistic children. According to Mudzakir and Sutrisno (1997), physiological factors including: illness, unhealthy and disabled body can affect the learning achievement of autistic children. A supportive environment for autistic children was needed in order to help the autistic children to grow with good nutritional status and achievement in school such as parental attention, the condition of parental economy, and the relationship between family members. Parental attention can be given in the form of affection, concern, and feeling of safe. The economic condition of parents would affect the availability of children's needs including nutritious food. With the availability of nutritious food, then the fulfillment of nutrients in autistic children would be well-fulfilled.

The result of this study was in line with a study by Fauzi et al. (2014) which stated that there was a relationship between nutritional status and learning achievement in students of SMP Negeri 22 Bandar Lampung. Positive impact that occur in children with good nutritional status was they were less likely to get sick because their immunological system was stronger so they would be more active in school and enhance their learning concentration in school. The enchancement of learning concentrations in school lead to the enchancement of grades in school, therefore, their learning achievement was increased. This strengthened the theory that nutritional status measurement instruments can be used for both autistic and normal children.

\section{The effect of family acceptance on learning achievement}

Family is the smallest unit of society consisting the head of the family and several people who gather and live in one place under one roof in a state of dependence (Setiawati, 2008). Every new family must expect a child. But the expected child was not always in accordance with the wishes, especially if the child was born with an abnormal condition such as autism. The common reaction of parents or family to the presence of children with autism were different (YPAC, 2014). In many places, autistic children were directly and indirectly tend to be excluded from the environment. The rejection toward them was not only done by other individuals, but some of them were not even accepted in their own families. Poor family acceptance can affect the growth and development of autistic children.

The result of path analysis in this study showed that there was no direct effect between family acceptance and learning achievement of autistic children, however, there was a direct positive relationship through nutritional status and autistic children's learning achievement. Good family acceptance can provide good parenting to the children, therefore, it can be said that family acceptance affected the children's nutritional status. According to Sugiarti and Pribadi (2012), family support is the main factor to support students' learning success. In other words, the learning achievement in school was affected by family support. Family support for children with autism can be given if the family has accepted the physical conditions of those autistic children. By accepting the child- 
ren's conditions, the family would try to provide all necessary needs, including fulfill their nutritional needs.

The result of this study was in line with a study done by Sadiyah (2009), which stated that parental acceptance of the children's conditions would significantly affect the self-actualization of children with physical disabilities in SLB D YPAC branch of Semarang. It can be said that the beginning of whether children with special needs can achieve a better condition or not was determined by the parental acceptance of their children. If the parental acceptance was good then it was certain that all aspects to support the children's development would be maximally fulfilled by the parents.

\section{REFERENCES}

Almatsier S (2004). Prinsip Dasar Ilmu Gizi. Jakarta: PT. Gramedia Utama.

Bauminger N, Kasari C (2000). Loneliness and friendship in high-functioning children with autism. Child Development, 71.

Budhiman M (2002). Langkah Awal Menanggulangi Autisme. Jakarta: Nirmala.

Crow LD, Alice (1989). Psikologi Pendidikan, terjemah Abd. Rachman Abror, Yogyakarta: Nur Cahaya.

Departemen Sosial (2008). Petunjuk Teknis Rehabilitasi Sosial Penyandang Cacat, Jakarta: Departemen Sosial

Doll EA (1953). Measurement of Social Competence: a manual for the Vineland Social Maturity Scale. Minneapolis: Educational Test Bureau, Educational Publishers

Hurlock EB (2006). Perkembangan Anak. Erlangga. Jakarta.

Makmun AS (1996). Psikologi Kependidikan Perangkat Sistem Pengajaran Modul. Bandung: Remaja Rosda- karya.

Mansjoer (2000). Kapita Selekta Kedokteran, ed.3, Media Aesculapius, Jakarta.

Mubarak WI (2007). Promosi Kesehatan Sebuah Pengantar Proses Belajar Mangajar dalam Pendidikan. Yogyakarta: Graha Ilmu.

Murti B (1996). Penerapan Metode Statistik Non Parametrik dalam Ilmu - Ilmu Kesehatan. Jakarta: Gramedia Pustaka Utama

(2011). Validitas dan Reliabilitas Pengukuran Matrikulasi Program Studi Doktoral Fakultas Kedokteran UNS. Surakarta: Universitas Sebelas Maret.

(2013). Desain dan Ukuran Sampel untuk Penelitian Kuantitatif dan Kualitatif di Bidang Kesehatan. Yoyakarta: Gadjah Mada University Press.

Nursalam (2005). Asuhan Keperawatan Bayi \& Anak (Untuk Perawat \& Bidan). Jakarta: Salemba Medika

Papalia \& Olds (2004). Human Development. New York: McGraw-Hill Book Co.

Pusponegoto HD, Solek P (2007). Apakah Anak Kita Autis?. Bandung: Trikarsa.

Sadiyah, SI (2009). Pengaruh Penerimaan Orangtua Tentang Kondisi Anak Terhadap Aktualisasi Diri Anak Penyandang Cacat Fisik Di SLB D YPAC Cabang Semarang Tahun 2009.

Santrock JW (2007). Life Span Development (12th Ed). New York: McGrawHill Book co.

Setiawati (2006). Optimalisasi Peran Wanita di Keluarga dalam Membentuk Sumber Daya Manusia Berkualitas.

Soetjiningsih (1995). Tumbuh Kembang Anak. Jakarta : EGC.

Somantri TS (2007). Psikologi Anak Luar Biasa. Bandung : PT Refika Aditama. 
Sumekar, G (2009). Anak Berkebutuhan Khusus. UNP, Padang : 325

Sunarto AH (1999). Perkembangan Peserta Didik. Jakarta : Rineka Cipta

Supariasa (2002). Penilaian Status Gizi. JakartA: Penerbit Kedokteran EGC.

Suprajitno (2004). Asuhan Keperawatan Keluarga Aplikasi Dalam Praktik. Jakarta: EGC.

Supartini Y (2007). Buku Ajar Konsep Dasar Keperawatan Anak. Jakarta: EGC.

Suriadi, Yuliani (2001). Asuhan Keperawatan Pada Anak. Jakarta: CV Sagung Seto.

Susilo HW (2014). Biostatistika Lanjut dan Aplikasi Riset. Jakarta Timur: Trans Info Media

Suryana A (2004). Terapi Autisme, Anak Berbakat dan Anak Hiperaktif. Jakarta: Progres Jakarta

Tulus Tu'u (2004). Peran Disiplin Pada Prilaku dan Prestasi Siswa. Jakarta:
Gramedia.

Republik Indonesia (2011). Undangundang nomor 19 tentang Pengesahan Convention on the Rights of Persons with Disabilities (Konvensi mengenai Hak-Hak Penyandang Disabilitas).

Wenar, Kerig (2006). Developmental Psychopathologi. United States: The McGraw-Hill Companies.

Widiatmoko F (2014). Korelasi Peran Orangtua dengan Pencapaian Prestasi Belajar Anak Autis di SLB Kabupaten Pamekasan. Jurnal Pendidikan Khusus: UNESA

Widihastuti S (2013). Pola Pendidikan Anak Autis. Yogyakarta: FNAC

Wong, Whaley (1995). Clinical Manual of Pediatric Nursing. Philadelphia. 